\title{
Analysis Of Factors Related To Anxiety Level In Postpartum Mothers at Citra Insani Maternity Home, Semarang
}

\author{
Yulvira Febriani*, Rasipin, Runjati \\ Poltekkes Kemenkes Semarang, Semarang, Indonesia \\ * virayulpira@gmail.com
}

\begin{abstract}
Anxiety disorders often occur in postpartum women. Studies on psychological disorders in the postpartum period are still limited in Indonesia. The cause of postpartum anxiety is still unknown. Many adverse developmental effects after anxiety can be caused to the mother, baby, and her family. The research aims to analyze factors related to postpartum anxiety level at Citra Insani Maternity Home, Semarang. This study used an analytic observational research design with a cross sectional approach. Sampling was conducted at the Citra Insani Maternity Hospital in Semarang City from February to March 2020 using purposive sampling. The study subjects are 40 postpartum mothers in the second day. The instrument used was a Postpartum Specific Anxiety Scale (PSAS) questionnaire. The factors studied were age, parity, education, employment status, and history of anemia. Data analysis was performed using the Chi-square test. The results is the majority of mothers experienced moderate anxiety $(60 \%)$. Based on data analysis, there is no significant relationship between age, parity, education, employment status and history of anemia with postpartum anxiety levels.
\end{abstract}

Keywords : Age, Anxiety, Education, Employment Status, History Of Anemia, Parity, Postpartum 


\section{STRADA Jurnal Ilmiah Kesehatan}

DOI: $10.30994 /$ sjik.v9i2.357

ISSN: 2252-3847 (print); 2614-350X (online)

Vol.9 No.2 November 2020 Page.670-677

\section{BACKGROUND}

The postpartum period is a time of great difficulty and emotional distress for some women (O'Hara, 2012). Anxiety disorders often occur in postpartum women (Goodman, Watson, \& Stubbs, 2016) and become a major component for almost all psychiatric disorders (Hawari, 2011). The cause of postpartum anxiety is still not known with certainty (Wahyuningsih, 2019).

Postpartum psychological problems are a trend that continues to increase in terms of maternal mortality. Many mothers are not asked about their mental well-being which indicates that their mental conditions may be overlooked (Baston \& Hall, 2017). At present research on psychological disorders or postpartum anxiety disorders is still limited in Indonesia (Goodman et al., 2016). Postpartum anxiety is often undetectable due to lack of reporting (Motzfeldt, Andreasen, Pedersen, \& Pedersen, 2013). Several previous studies have shown a wide prevalence of postpartum anxiety ranging from $13 \%$ to $40 \%$ (Field, 2017). Based on World Health Organization (WHO), around $13 \%$ of postpartum mothers experience mental disorders worldwide (World Health Organization, n.d.), while in Indonesia anxiety occurs in the range of $11 \%$ to $30 \%$ in women in the postpartum period (Lestari, 2017).

Much evidence shows that postpartum anxiety is closely related to adverse maternal physiological and psychological adjustments. Anxiety adversely impacts the recovery and breastfeeding process of mothers in the early postpartum period (Kuo, Tsai, Chen, \& Tzeng, 2016). Anxiety is associated with substantial negative effects on children's social, emotional and academic success. If not resolved immediately, anxiety symptoms persist and are associated with significant deterioration in function, poor quality of life, and enormous economic burdens (Soodan \& Arya, 2015), until they develop into postpartum blues or postpartum depression (Yunita, Mahpolah, \& Wulandari, 2013).

Midwives have an important role in identifying women who are at risk of mental disorders after childbirth (Baston \& Hall, 2017). In connection with the problem above, it is important to know the factors associated with postpartum anxiety levels at the Citra Insani Maternity Home in Semarang. Thus, anxiety disorders that occur in postpartum mothers can be detected early so as not to cause more serious psychological disorders.

\section{METHODS}

This study uses an observational analytic research design with a cross sectional approach. This research was conducted at the Citra Insani Maternity Home Semarang City from February to March 2020. Samples were taken by purposive sampling method. The subjects of this study were the second day normal postpartum mother who had vaginal delivery and had normal vital signs. There were 40 respondents who met the criteria and agreed to participate. The instrument used to measure anxiety levels was the Postpartum Specific Anxiety Scale (PSAS) questionnaire. The Indonesian version of the PSAS questionnaire was tested for validity and reliability which resulted in an assessment of Cronbach's alpha 0.990 (Ekawati, Setyowati, \& Budiati, 2019). The data obtained were analyzed using the Chi-Square test $(\alpha=0.05)$.

\section{RESULTS}

The research sample consisted of 40 respondents with 16 respondents who experienced mild anxiety and 24 respondents who experienced moderate anxiety. In the Table 1, we known that the frequency distribution of postpartum maternal anxiety levels 


\section{STRADA Jurnal Ilmiah Kesehatan}

DOI: $10.30994 /$ sjik.v9i2.357

ISSN: 2252-3847 (print); 2614-350X (online)

Vol.9 No.2 November 2020 Page.670-677

based on age shows that the number of respondents in the age range of 20 to 28 years $(52.5 \%)$ is more than the number of respondents in the age range of 29 to 35 years (47.5\%). In the age group of 20 to 28 years who experienced moderate anxiety as many as 12 people (30\%) and mild anxiety as many as 9 people $(22.5 \%)$, while in the age group of 29 to 35 years who experienced moderate anxiety as many as 12 people (30\%) and mild anxiety of 7 people (17.5\%).

Based on parity, the number of multipara respondents $(80 \%)$ is higher than primipara (20\%). In the primiparous group of mothers who experienced mild anxiety as many as 3 people $(7.5 \%)$ and moderate anxiety as many as 5 people (12.5\%), while in the group of multiparous mothers who experienced mild anxiety as many as 13 people $(32.5 \%)$ and anxiety while as many as 19 people $(47.5 \%)$.

Characteristics of respondents based on education known to the number of respondents with low education $(70 \%)$ more than higher education $(30 \%)$. Mothers with low education experienced mild anxiety by 13 people $(32.5 \%)$ and moderate anxiety by 15 people (37.5\%), while mothers with higher education experienced mild anxiety by 3 people $(7.5 \%)$ and moderate anxiety by as many as 9 people $(22.5 \%)$.

If seen from the characteristics of respondents based on employment status, there are more mothers who are not working (62.5\%) compared to working mothers $(37.5 \%)$. Mothers who do not work experience mild anxiety as many as 13 people $(32.5 \%)$ and moderate anxiety as many as 12 people $(30 \%)$, while working mothers experience mild anxiety as many as 3 people $(7.5 \%)$ and moderate anxiety as many as 12 people $(30 \%)$.

On the characteristics of mothers based on a history of anemia known to the number of mothers without a history of anemia $(72.5 \%)$ more than mothers with a history of anemia (27.5\%). Mothers without a history of anemia experienced anxiety by 12 people $(30 \%)$ and mild anxiety by 17 people (42.5\%), while mothers with a history of anemia who experienced mild anxiety by 4 people (10\%) and moderate anxiety by 7 people $(17.5 \%)$.

The results of the data analysis test used the Chi-Square test to determine the relationship between variables with the level of postpartum maternal anxiety (Table 2) showing that the variables of age, parity, education, employment status, and history of anemia obtained $p$-value> 0.05 . This shows that there is no relationship between the variables of age, parity, employment status, and history of anemia with the level of postpartum maternal anxiety on the second day at the Citra Insani Maternity Home in Semarang.

\section{DISCUSSION}

\section{Relationship between Age and Postpartum Anxiety Level}

The characteristics of mothers by age (Table 1) show both groups of mothers with an age range of 20 to 28 years and 29 to 35 years the majority experienced moderate anxiety. Statistical test results obtained $p$ value $=0.948$ ( $p>0.05)$, which means there is no relationship between age and postpartum maternal anxiety levels. The results of this study are in line with research by Kusmiyati et al and Komariah which show that maternal age does not have a significant relationship with postpartum maternal anxiety.(Komariah, 2017; Kusmiyati \& Wahyuningsih, 2014) In line with the results of other studies, age does not affect anxiety and stress because there are other factors that can affect a person's level of maturity cannot be determined through how old primiparous women are (Gurnita, Suwondo, \& Astuti, 2020).

This contradicts the research results of Yunita et al and Kurniasari \& Astuti which 


\section{STRADA Jurnal Ilmiah Kesehatan}

DOI: $10.30994 /$ sjik.v9i2.357

ISSN: 2252-3847 (print); 2614-350X (online)

Vol.9 No.2 November 2020 Page.670-677

states that there is a significant relationship between age and anxiety level of postpartum mothers (Kurniasari \& Astuti, 2015; Yunita et al., 2013). Although in this study it was seen that all respondents were in the safe age category and were ideal for undergoing the process of pregnancy and childbirth, namely in the age range of 20 to 35 years. This is in accordance with the appeal of the National Family Planning Coordinating Board (BKKBN) which states that it is better for women to get married at the age of 20 year, so that many people choose to marry within that age range. In this age range, a woman is considered to be ready physically and psychologically to give birth and care for children, because the level of maturity, ways of thinking and behaving will increase with age. Very young mothers who are prone to experience anxiety. This is due to the lack of skills that he mastered related to baby care, unable to accept changes in his lifestyle, and fatigue caring for his baby (Yunita et al., 2013).

\section{Relationship between Parity and Postpartum Anxiety Level}

Characteristics of respondents based on parity have a number of multipara respondents as many as 32 people (80\%) more than primipara, amounting to 8 people $(20 \%)$. Statistical test results show the value of $p=0.601(p>0.05)$, meaning that there is no relationship between parity and anxiety level in postpartum mothers. This result is in line with Kirana's research which shows that there is no relationship between parity and postpartum blues events (Kirana, 2015).

This contradicts previous research showing that there are differences in anxiety levels in primiparous and multiparous parity mothers (Bentelu, Kundre, \& Bataha, 2015), which means there is a significant relationship between parity and anxiety of postpartum mothers (Rahmaningtyas, Winarni, Mawarni, \& Dharminto, 2019). According to the results of previous studies it is known that some postpartum mothers who suffer from anxiety are primipara. (Wahyuningsih, 2019) Primiparous mothers experience higher anxiety than multiparous mothers, because primiparous mothers still need to adapt to postpartum conditions (Wahyuningsih, 2019), are required to be able to breastfeed and care for their babies. A multipara has previously had the responsibility as a mother and has cared for babies so that they do not experience difficulties during childbirth (Wahyuningsih, 2019).

\section{Relationship of Education with Postpartum Anxiety Level}

Characteristics of respondents based on education found that the majority of mothers had a low level of education of 28 people (70\%) compared to mothers with a high level of education of 12 people (30\%). Mothers with low levels of education experience the most anxiety. Statistical test results obtained $p$ value $=0.297(p>0.05)$, which means there is no relationship between education and the level of postpartum maternal anxiety. These results are in line with several previous studies, which are known that maternal education variables do not have an effect on postpartum maternal anxiety (Gurnita et al., 2020; Hayati, 2018; Hayati, Herman, \& Agus, 2017; Kusmiyati \& Wahyuningsih, 2014).

Mothers with low levels of education are more likely to experience stress and worry about passing on their role as mothers. Mothers with higher education will find it easier to receive and understand information that will influence a constructive and realistic mindset for dealing with problems. A higher level of education is expected to increase understanding and knowledge to overcome problems in the postpartum period. Education cannot be an absolute parameter to increase knowledge. Knowledge 


\section{STRADA Jurnal Ilmiah Kesehatan}

DOI: $10.30994 /$ sjik.v9i2.357

ISSN: 2252-3847 (print); 2614-350X (online)

Vol.9 No.2 November 2020 Page.670-677

enhancement can be obtained through non-formal education, the interaction of the social physical environment and information media (Gurnita et al., 2020).

\section{Relationship of Employment Status with Postpartum Anxiety Level}

When seen from the characteristics of respondents based on employment status, the number of respondents who did not work was more, namely 25 people $(62.5 \%)$, while respondents who worked were 15 people (37.5\%). Statistical test results to determine the relationship between occupational status and anxiety level of postpartum mothers obtained $p=0.096$ ( $p>0.05$ ). So it can be concluded that the results of this study indicate that there is no significant relationship between the occupational status of mothers with the level of anxiety experienced by postpartum mothers. This is in line with the research of Kusmiyati et al., Gurnita et al., and Hayati which shows that maternal employment status does not affect the level of postpartum maternal anxiety.(Gurnita et al., 2020; Hayati, 2018; Hayati et al., 2017; Kusmiyati \& Wahyuningsih, 2014)

This contradicts the results of Kurniasari \& Astuti's research which shows that there is a significant relationship between maternal work and the incidence of postpartum blues (Kurniasari \& Astuti, 2015). Previous literature studies suggest that most postpartum mothers who work experience anxiety. Generally working women will feel satisfied with their work. But when he already has children, job satisfaction can decrease. This is due to the feeling of guilt that he felt because he had left his child or felt too focused on his work so that he ignored his child (Wibisono, 2018). The effects of work arises due to the existing workload, multiple role conflicts that create new problems for women who work and eventually cause emotional disturbances if during the postpartum period does not go well Kurniasari \& Astuti, 2015).

\section{Relationship between Anemia History and Postpartum Anxiety Level}

The number of respondents based on a history of anemia found mothers without a history of anemia (72.5\%) more than mothers with a history of anemia (27.5\%). Statistical test results showed that there was no significant relationship between history of maternal anemia with maternal anxiety levels postpartum with indicated $\mathrm{p}$ value = 0.533 ( $p>0.05$ ). This contradicts the research of Rahmaningtyas et al which shows that there is a significant relationship between history of anemia and postpartum maternal anxiety with a p value of 0.012 ( $\mathrm{p}<0.05)$ (Rahmaningtyas et al., 2019).

Pregnant women are said to have anemia if they have a hemoglobin $(\mathrm{Hb})$ level $<11$ gr/dL. Pregnant women experience iron deficiency or reduction, iron deficiency affects the decrease in levels of serotonin and dopamine in the brain, causing symptoms of depression, one of which is anxiety. Mothers with a history of anemia during pregnancy will tend to have a higher anxiety disorder than mothers who do not have anemia while pregnant. Multivariate analysis in previous studies showed that a history of anemia during pregnancy was the most dominant factor influencing postpartum anxiety. Mothers with a history of anemia are 3,384 times more likely to have anxiety in the postpartum period than women who have no history of anemia during pregnancy (Rahmaningtyas et al., 2019). So, mothers who have low Hb levels during pregnancy will be more prone to experience fatigue and anxiety, especially during to take care of them self and their baby.

Postpartum anxiety levels based on PSAS scores are considered mild if they have a score of $\leq 73$, moderate anxiety between 74 and 100, and high anxiety score $\geq 101$. Higher scores indicate higher anxiety as well (Duran, 2019). Midwives have an important role in identify women who are at risk of postpartum mental disorders. Post- 


\section{STRADA Jurnal Ilmiah Kesehatan}

DOI: $10.30994 /$ sjik.v9i2.357

ISSN: 2252-3847 (print); 2614-350X (online)

Vol.9 No.2 November 2020 Page.670-677

delivery service providers must invest in evidence-based care to support mothers and their families (Baston \& Hall, 2017).

\section{CONCLUSION}

Characteristics of postpartum mothers at Citra Insani Semarang Maternity Hospital based on the age of majority are in the age range of 20 to 28 years (525\%), multipara parity $(80 \%)$, low education (70\%), employment status not working $(62.5 \%)$, and without a history of anemia (72.5\%). The most anxiety level experienced by respondents is moderate anxiety (60\%). There was no significant relationship between age, parity, education, employment status, and history of anemia with anxiety levels during the postpartum period. Future studies are expected to examine other factors that can affect postpartum anxiety

\section{REFERENCES}

Baston, H., \& Hall, J. (2017). Midwifery Essentials : Postnatal E-Book, Volume 4 (2nd ed). Edinburgh, London, New York, Oxford, Philadelphia, St Louis, Sydney, Toronto: Elsevier Health Sciences.

Bentelu, F. E. M., Kundre, R., \& Bataha, Y. B. (2015). Perbedaan tingkat kecemasan dalam proses menyusui antara ibu primipara dan multipara di RS Pancaran Kasih GMIM Manado. e-journal Keperawatan, 3(2), 1-7.

Duran, S. (2019). Postpartum Specific Anxiety Scale (PSAS): Reliability and validity of the Turkish version. Perspect Psychiatr Care, (December 2017), 1-7. https://doi.org/10.1111/ppc.12385

Ekawati, E., Setyowati, S., \& Budiati, T. (2019). "Sehati"” health education to improve physical and psychological adaptation of the postpartum women having preeclampsia. Enfermeria Clinica, 29(S2), 199-204. https://doi.org/10.1016/j.enfcli.2019.04.054

Field, T. (2017). Postpartum anxiety prevalence, predictors and effects on child development: a review. Journal of Psychiatry and Psychiatric Disorders, 1(2), 86-102.

Goodman, J. H., Watson, G. R., \& Stubbs, B. (2016). Anxiety disorders in postpartum women: a systematic review and meta-analysis. Journal of Affective Disorders, 203, 292-331. https://doi.org/10.1016/j.jad.2016.05.033

Gurnita, F. W., Suwondo, A., \& Astuti, R. S. E. P. (2020). Faktor yang mempengaruhi tingkat kecemasan postpartum primipara. JIKA, 4(2), 42-46.

Hawari, D. (2011). Manajemen Stres Cemas dan Depresi. Jakarta: Balai Penerbit FKUI.

Hayati, F. (2018). Perbedaan tingkat kecemasan ibu bersalin di puskesmas dengan di bidan praktik mandiri. Jurnal Akademika Baiturrahim, 7(1), 85-91.

Hayati, F., Herman, R. B., \& Agus, M. (2017). Perbedaan tingkat kecemasan ibu bersalin di puskesmas dengan di bidan praktik mandiri dan hubungannya dengan lama persalinan. Jurnal Kesehatan Andalas, 6(3), 564-571.

Kirana, Y. (2015). Hubungan tingkat kecemasan post partum dengan kejadian post partum blues di Rumah Sakit Dustira Cimahi. Jurnal Ilmu Keperawatan, III(1), 25-37.

Komariah, N. (2017). Hubungan antara usia ibu dengan tingkat kecemasan ibu postpartum di BPM Teti Herawati Palembang. Jurnal Kesehatan Palembang, 12(2), 103-107.

Kuo, S., Tsai, S., Chen, S., \& Tzeng, Y. (2016). Auricular acupressure relieves anxiety and fatigue, and reduces cortisol levels in post-caesarean section women: A single- 


\section{STRADA Jurnal Ilmiah Kesehatan}

DOI: $10.30994 /$ sjik.v9i2.357

ISSN: 2252-3847 (print); 2614-350X (online)

Vol.9 No.2 November 2020 Page.670-677

blind, randomised controlled study. International Journal of Nursing Studies, 53, 17-26. https://doi.org/10.1016/j.ijnurstu.2015.10.006

Kurniasari, D., \& Astuti, Y. A. (2015). Hubungan antara karakteristik ibu, kondisi bayi dan dukungan sosial suami dengan postpartum blues pada ibu dengan persalinan SC di Rumah Sakit Umum Ahmad Yani Metro Tahun 2014. Jurnal Kesehatan Holistik, 9(3), 115-125.

Kusmiyati, Y., \& Wahyuningsih, H. P. (2014). Pengaruh hypnobreastfeeding terhadap kecemasan dan waktu pengeluaran air susu ibu pada ibu post partum primipara di Yogyakarta. Jurnal Teknologi Kesehatan, 10(2), 123-127.

Lestari, E. (2017). Hubungan antara paritas dengan tingkat kecemasan yang dialami ibu pada masa post partum di RS PKU Muhammadiyah Yogyakarta. Universitas 'Aisyiyah Yogyakarta.

Motzfeldt, I., Andreasen, S., Pedersen, A. L., \& Pedersen, M. L. (2013). Prevalence of postpartum depression in Nuuk, Greenland - a cross-sectional study using Edinburgh Postnatal Depression Scale. International Journal of Circumpolar Health ISSN:, 72(1), 1-6.

O'Hara, M. W. (2012). Postpartum depression: causes and consequences (series in psychopathology). New York: Springer-Verlag.

Rahmaningtyas, I., Winarni, S., Mawarni, A., \& Dharminto. (2019). Hubungan beberapa faktor dengan kecemasan ibu nifas di wilayah kota Semarang. Jurnal Kesehatan Masyarakat, 7(4), 303-309.

Soodan, S., \& Arya, A. (2015). Understanding the pathophysiology and management of the anxiety disorders. International Journal of Pharmacy \& Pharmaceutical Research, 4(3), 251-278.

Wahyuningsih, J. W. (2019). The relationship of family support with the post partum anxiety. Jurnal Kebidanan Indonesia, 10(1), 30-38.

Wibisono, A. (2018). Hubungan Karakteristik Personal Dengan Kecemasan Pada Ibu Postpartum di Wilayah Kerja Puskesmas Gatak Sukoharjo. Universitas Muhammadiyah Surakarta.

World Health Organization. (n.d.). Maternal mental health. Opgehaal van https://www.who.int/mental_health/maternal-child/maternal_mental_health/en/

Yunita, L., Mahpolah, \& Wulandari, D. R. (2013). Hubungan umur dengan tingkat kecemasan ibu primipara pada masa nifas di wilayah kerja Puskesmas Kertak Hanyar. Dinamika Kesehatan, 4(2), 84-92. 


\section{STRADA Jurnal Ilmiah Kesehatan}

DOI: $10.30994 /$ sjik.v9i2.357

ISSN: 2252-3847 (print); 2614-350X (online)

Vol.9 No.2 November 2020 Page.670-677

Table 1. Frequency Distribution of Postpartum Anxiety Levels

\begin{tabular}{|c|c|c|c|c|c|c|}
\hline \multirow{3}{*}{ Variables } & \multicolumn{4}{|c|}{ Anxiety Levels } & \multirow{2}{*}{\multicolumn{2}{|c|}{ Total }} \\
\hline & \multicolumn{2}{|c|}{ Mild } & \multicolumn{2}{|c|}{ Moderate } & & \\
\hline & $\mathbf{f}$ & $\%$ & $\mathbf{f}$ & $\%$ & $\mathbf{f}$ & $\%$ \\
\hline \multicolumn{7}{|l|}{ Age } \\
\hline - 20-28 year & 9 & 22,5 & 12 & 30 & 21 & 52,5 \\
\hline - 29-35 year & 7 & 17,5 & 12 & 30 & 19 & 47,5 \\
\hline \multicolumn{7}{|l|}{ Parity } \\
\hline - Primipara & 3 & 7,5 & 5 & 12,5 & 8 & 20 \\
\hline - Multipara & 13 & 32,5 & 19 & 47,5 & 32 & 80 \\
\hline \multicolumn{7}{|l|}{ Education } \\
\hline - Low & 13 & 32,5 & 15 & 37,5 & 28 & 70 \\
\hline - High & 3 & 7,5 & 9 & 22,5 & 12 & 30 \\
\hline \multicolumn{7}{|l|}{ Employment Status } \\
\hline - Not Work & 13 & 32,5 & 12 & 30 & 25 & 62,5 \\
\hline - Work & 3 & 7,5 & 12 & 30 & 15 & 37,5 \\
\hline \multicolumn{7}{|l|}{ History of Anemia } \\
\hline - Not Anemia & 12 & 30 & 17 & 42,5 & 29 & 72,5 \\
\hline - $\quad$ Anemia & 4 & 10 & 7 & 17,5 & 11 & 27,5 \\
\hline Total & 16 & 40 & 24 & 60 & 40 & 100 \\
\hline
\end{tabular}

Tabel 2. Statistical Test Results

\begin{tabular}{lccc}
\hline \multicolumn{1}{c}{ Variables } & P-value & OR & CI 95\% \\
\hline Age & 0,948 & 1,286 & $0,361-4,584$ \\
Parity & 0,601 & 0,877 & $0,178-4,325$ \\
Education & 0,297 & 2,600 & $0,578-11,687$ \\
Employment Status & 0,096 & 4,333 & $0,978-19,202$ \\
History of Anemia & 0,533 & 1,235 & $0,295-5,181$ \\
\hline
\end{tabular}

